\title{
Vegetative Differences Among Active and Abandoned Towns of Black-tailed Prairie Dogs (Cynomys ludovicianus)
}

\section{LOIS E. KLATT AND DALE HEIN}

Highlight: Vegetational differences were studied among one active prairie dog (Cynomys ludovicianus) town and three towns which had been abandoned 1, 2, and 5 years, respectively. Blue grama (Bouteloua gracilis) and buffalograss (Buchloe dactyloides) were dominant on all four study areas. Percent cover of total vegetation, grasses, and increaser and invader species declined with length of abandonment. Percent cover of the only decreaser, western wheatgrass (Agropyron smithii), was similar on the

The authors are biometrician, West Virginia Department of Natural Resources, Post Office Box 67, Elkin 26241; and associate professor, Department of Fishery and Wildlife Biology. Forestry Building. Colorado State University, Fort Collins 80523.

Manuscript received June 10, 1977. abandoned towns and lowest on the active town. Composition of vegetation on the four study areas did not indicate that the usual stages of secondary succession on short grass prairie had occurred on the abandoned prairie dog towns. Most changes in vegetation following abandonment of 5 years or less by prairie dogs were apparently relatively minor and would not benefit cattle grazing significantly.

The objective of this study was to describe differences in vegetation among an active prairie dog town and towns abandoned for different numbers of years in shortgrass prairie. Koford (1958) compared vegetation of an active town and adjacent rangeland in shortgrass prairie and found that total plant cover was approximately twice as great in the town as it was outside. Koford also found that total cover in an area of the town occupied by prairie dogs for several years was 
greater than in a newly occupied area. Himes (1966) found that total cover in a town that had been abandoned for 2 years was $14 \%$, compared to $35 \%$ when the town was occupied. Bonham and Lerwick (1976) reported that grazing by black-tailed prairie dogs favored increase of buffalograss, invasion of annuals, and more species present due to selective grazing on a few preferred species, including blue grama.

\section{Study Area and Methods}

This study was conducted $11 \mathrm{~km}$ north of Fort Collins, Colo., in an area of 35 to $40 \mathrm{~cm}$ mean annual precipitation. The climate supports a shortgrass prairie dominated by buffalograss and blue grama, with western wheatgrass common.

Data were collected on four study areas. Study area A was an active town. Because of prairie dog eradication activities, area B had been abandoned for 1 year, area $C$ for 2 years, and area $D$ for 5 years prior to this study. Area B had been occupied by prairie dogs for 3 or 4 years before being poisoned. The other three areas had been occupied by prairie dogs for at least 36 years before areas $C$ and $D$ were poisoned.

Areas A, C, and D were located on loamy plains soils, while area B was on loamy foothills soil (U.S. Dep. Agr. 1968). Blue grama is the potential dominant on loamy plains soils, and western wheatgrass is the potential dominant on loamy foothills soil. All four areas were native grasslands that were moderately grazed part of the year by cattle.

Vegetation was sampled during June-August by means of a grid of points in a frame $0.5 \mathrm{~m}$ square, in a variation of the point frame method (Cook and Box 1961). The square frame was crossed at top and bottom by eight equally spaced wires, four in each direction, resulting in a set of 16 points $20 \mathrm{~cm}$ directly above a second set of 16 points. In the field, the vegetation or soil directly under each vertical pair of 16 aligned points in the grid was recorded. When more than one layer of vegetation occurred under a point, the top layer was recorded; this occurred less than $1 \%$ of the time.

Vegetation was sampled systematically at 3-m intervals along two transects that crossed the town at the area of greatest concentration of burrows and proceeded to the edges of the town. One transect ran magnetic north to south, the other east to west. Data were recorded for 100 to 200 grids (1,600 to 3,200 points) per study area.

Criteria of Stoddart and Smith (1975) were used, where decreaser refers to species that decrease under grazing pressure, increaser to species that increase under grazing, and invaaier to species not present in the climax vegetation but which invade following grazing. Percent cover for each plant species was computed as the percent of the total number of points for an area in which the species was recorded.

\section{Results}

Most of the species recorded were increasers or invaders; only one,

Table 1. Vegetation on one active $(A)$ and three abandoned $(B=1$ year, $C=2$ years, $D=5$ years) prairie dog towns, Larimer County, Colo.

\begin{tabular}{|c|c|c|c|c|c|}
\hline \multirow[b]{3}{*}{ Species $^{1}$} & \multirow[b]{3}{*}{ Status $^{2}$} & \multicolumn{4}{|c|}{ Pcrcent cover } \\
\hline & & \multicolumn{4}{|c|}{ Area } \\
\hline & & $\Lambda$ & B & $\mathrm{C}$ & D \\
\hline Agropyron smithii & 1 & 2.3 & 5.1 & 6.9 & 6.7 \\
\hline Muhlengergia torreyi & 3 & 5.5 & 0.2 & 9.0 & 0.7 \\
\hline Oryzopsis hymenoides & $\mathrm{x}$ & & & & 0.6 \\
\hline Aristida longiseta & 2 & 2.8 & 0.4 & 0.2 & 0.3 \\
\hline Bouteloua gracilis & 2 & 20.7 & 22.8 & 9.8 & 22.2 \\
\hline Buchloe dactyloides & $2(3$ on $B)$ & 37.2 & 32.4 & 31.9 & 25.0 \\
\hline Perennial grasses (subtotal) & & 68.5 & 60.8 & 57.7 & 55.2 \\
\hline Annual grasses (2 spp.) & $\mathrm{x}$ & & $0.1-$ & & 0.5 \\
\hline Forbs (14 spp.) & $2,3, x$ & $0.1-$ & 2.2 & 0.6 & 0.4 \\
\hline Shrubs/half-shrubs (6 spp.) & $2,3, x$ & 2.1 & 2.7 & 1.9 & 2.0 \\
\hline Total vegetation (27 spp.) & & 70.7 & 65.5 & 60.3 & 58.3 \\
\hline
\end{tabular}

Species with $>0.5 \%$ cover are listed individually; complete data and list of all 27 species recorded is available upon request from authors.

Status: 1 = decreaser, 2 = increaser, $3=$ invader, $x=$ undetermined (Stoddart and Smith 1975). western wheatgrass, was a decreaser (Table 1). Total number c species recorded differed among the four study areas because of th varying number of species of forbs present on different areas. Only on species of forb was recorded on area $A$. In $C$ and $D$, five and thre species of forbs were recorded, respectively. Area B, however, had 1 species of forbs. Similarly, the total number of plant species wa lowest in area A (11), highest in B (23), and low in C and D (15 specie each).

In each area two or three species dominated, and the remainin cover was distributed fairly evenly among the remaining specie (Table 1). In each area buffalograss dominated the cover, with blu grama second. Forbs and shrubs were numerous, but each specir comprised less than $2 \%$ of the total cover (Table 1).

Total plant cover ranged from $70.7 \%$ in ara $\mathrm{A}$ to $58.3 \%$ in area (Table 1). Most of this difference appeared in the grass componen which ranged from $68.5 \%$ in area $A$ to $5.9 \%$ in D. Percent cover $f_{i}$ increaser and invader grasses, including the dominant buffalogra and blue grama, declined between areas $A$ and $D$, while percent cov for the one decreaser, western wheatgrass, was lowest on area A ar similar among the three abandoned towns (Table 1).

Percent cover of forbs showed the same trend among areas as $d$ number of species of forbs (Table 1). Percent cover of forbs was lowe in area $\mathrm{A}$, low in $\mathrm{C}$ and $\mathrm{D}$, but higher in $\mathrm{B}$. Within the forb compone of vegetation, both annual and perennial invaders and perennial forl showed the same trends among areas as did total forbs.

\section{Discussion}

Composition of vegetation on the four study areas did not indica that the stages of secondary succession described by Costello (194 for this region had occurred on the abandoned prairie dog town Russian thistle (Salsola kali), which dominated the first stage succession described by Costello, occurred only in area $\mathrm{C}$ as a min species. Slimflower scurfpea (Psoralea tenuiflora), scarlet glob mallow (Sphaeralcea coccinea), silky sophora (Sophora sericea), ar red threeawn (Aristida longiseta), which were mentioned by Costel in the second stage of succession, appeared in area B (abandoned year). Also, according to Costello, annual plants were important ear in succession and perennial plants became important in later stages. our study, the percent cover of annual forbs, perennial forbs, ar grasses all declined between area A (active) and D (abandoned years).

It appeared, then, that prairie dog activities on these study areas d not cause the rangeland to revert to an appreciably earlier stage succession. The dominant species on all four study areas agreed for $\mathrm{tl}$ most part with those listed by Tileston (1961) for prairie dog towns c shortgrass prairie.

Percent cover for the decreaser, western wheatgrass, was sligh1 higher on the abandoned towns than on the active town. Howevt percent cover declined for the increasers and invaders from area A area $B$. These data indicated that, in terms used for rangeland graz by cattle, range condition improved slightly following eradication prairie dogs.

Koford (1958), among others, found that the mounds of bare si around prairie dog burrows were invaded by forbs following abando ment. This could explain the highest percent cover and most speci for forbs occurring on area $\mathrm{B}$, while these were lowest on area $\mathrm{A}$. Fi (1966) reported a similar response to cessation of cattle grazing; for immediately increased greatly. Results of our study indicated th removal of prairie dogs affected range similarly to removal of cattle this respect.

In contrast to this study and others on shortgrass prairie, Sm (1967) found that on tallgrass prairie percent cover was higher adjacent range than on active prairie dog towns. It should be noted th percent cover is not strictly analogous to production (Bjugstad a Whitman 1970).

Since data were taken from four different towns rather than from $t$ same town over 5 years, variables other than length of time sin abandonment could have influenced the results. For example, due differences in soils, the potential dominant on area B was weste 
wheatgrass, while the potential dominant on the other three towns was blue grama. Thus, one would expect to find more western wheatgrass on area B. However, this was not the case. Apparently, grazing influence of prairie dogs was more important than soil type in determining percent cover of western wheatgrass.

In summary, following abandonment of prairie dog towns in shortgrass prairie in northeast Colorado, results of this study indicated decreases in total vegetative cover and in percent cover of all grasses combined, which includes the dominant plant species. Only western wheatgrass increased slightly. Most changes were relatively minor except for markedly more species of forbs in the area abandoned by prairie dogs for 1 year compared to the other areas. Results of this study indicated that eradication of prairie dogs would not significantly improve shortgrass prairie for cattle during the first few years following abandonment of the towns.

\section{Literature Cited}

Bjugstad, A. J., and W. C. Whitman. 1970. Significance of reduced plant vigor in relation to range condition. J. Range Manage. 23:181-184.
Bonham, C. D., and A. C. Lerwick. 1976. Vegetation changes induced by prairie dogs on shorgrass range. J. Range Manage. 29:221-225.

Cook, C. W., and T. W. Box. 1961. A comparison of the loop and point methods of analyzing vegetation. J. Range Manage. 14:22-27.

Costello, D. F. 1944. Natural revegetation of abandoned plowed land in the mixed prairie of northeastern Colorado. Ecology 25:312-326.

Fish, E. B. 1966. Secondary succession on upper Kowa Creek watershed. MS Thesis, Colorado State Univ., Fort Collins. $102 \mathrm{p}$.

Himes, D. P. 1966. Behavior in an incipient black-tailed prairie dog town. MS Thesis, Colorado State Univ., Fort Collins. 57 p.

Koford, C. B. 1958. Prairie dogs, whitefaces, and blue grama. Wildl. Monogr. No. $3.78 \mathrm{p}$

Smith, R. E. 1967. Natural history of the prairie dog in Kansas. Univ. of Kansas Mus. Natur. Hist. and State Biol. Surv., Misc. Pub. No. 16. 36 p

Stoddart, L. A., A. D. Smith, and T. W. Box. 1975. Range Management. 3 rd ed. McGraw-Hill Book Co. Inc., New York. 433 p.

Tileston, J. V. 1961. Comparison of a white-tailed prairie dog town with a black-tailed prairie dog town in northcentral Colorado. MS Thesis, Colorado State Univ., Fort Collins. 139 p.

U.S. Department of Agriculture, Soil Conservation Service. 1968. Range site description, Colorado, range site no. 2 and $202.2+2 p$. 